\title{
Combined Use of Endophytic Bacteria and Pre-Sowing Treatment of Thiamine Mitigates the Adverse Effects of Drought Stress in Wheat (Triticum aestivum L.) Cultivars
}

\author{
Syeda Fasiha Amjad 1,*, Nida Mansoora ${ }^{1}$, Samia Yaseen ${ }^{1}$, Afifa Kamal ${ }^{2}$, Beenish Butt ${ }^{3}$, Humera Matloob ${ }^{1}$, \\ Saad A. M. Alamri ${ }^{4}$, Sulaiman A. Alrumman ${ }^{4} \mathbb{D}^{D}$, Ebrahem M. Eid ${ }^{4,5}{ }^{D}$ and Muhammad Shahbaz ${ }^{1}$ \\ 1 Department of Botany, University of Agriculture Faisalabad, Punjab 38000, Pakistan; \\ nidamansoora6@gmail.com (N.M.); samiayasin69@gmail.com (S.Y.); humera1359@gmail.com (H.M.); \\ shahbazmuaf@yahoo.com (M.S.) \\ 2 School of Life Sciences, Nanjing Normal University, Nanjing 210000, China; afifakamal05@gmail.com \\ 3 Soil and Water Testing Laboratory for Research Multan, Punjab 60000, Pakistan; beenish.butt@gmail.com \\ 4 Biology Department, College of Science, King Khalid University, Abha 61321, Saudi Arabia; \\ saralomari@kku.edu.sa (S.A.M.A.); salrumman@kku.edu.sa (S.A.A.); ebrahem.eid@sci.kfs.edu.eg (E.M.E.) \\ 5 Botany Department, Faculty of Science, Kafrelsheikh University, Kafr El-Sheikh 33516, Egypt \\ * Correspondence: fasihamushadi75@gmail.com
}

Citation: Amjad, S.F.; Mansoora, N.; Yaseen, S.; Kamal, A.; Butt, B.; Matloob, H.; Alamri, S.A.M.; Alrumman, S.A.; Eid, E.M.; Shahbaz, M. Combined Use of Endophytic Bacteria and Pre-Sowing Treatment of Thiamine Mitigates the Adverse Effects of Drought Stress in Wheat (Triticum aestivum L.) Cultivars. Sustainability 2021, 13, 6582. https://doi.org/10.3390/su13126582

Academic Editors: Rahul Datta, Subhan Danish and Shah Fahad

Received: 7 May 2021

Accepted: 6 June 2021

Published: 9 June 2021

Publisher's Note: MDPI stays neutral with regard to jurisdictional claims in published maps and institutional affiliations.

Copyright: (c) 2021 by the authors. Licensee MDPI, Basel, Switzerland. This article is an open access article distributed under the terms and conditions of the Creative Commons Attribution (CC BY) license (https:// creativecommons.org/licenses/by/ $4.0 /)$.
Abstract: On a global scale, wheat (Triticum aestivum L.) is a widely cultivated crop among all cereals. Increasing pollution, population expansion, socio-economic development, ecological and industrial policies have induced changes in overall climatic attributes. The impact of these factors on agriculture dynamics has led to various biotic and abiotic stresses, i.e., significant decline in rainfall, directly affect sustainable agriculture. Increasing abiotic stresses have a direct negative effect on worldwide crop production. More promising and improved stress-tolerant strategies that can help to feed the increasing global population are required. A laboratory experiment was performed on two of the latest wheat (Triticum aestivum L.) genotypes (Akbar 2019 and Anaj 2017) from Punjab Pakistan, to determine the influence of seed priming with thiamine (vitamin B1) along with soil inoculation of Endophytic bacterial strains to mitigate the effects of drought stress at different degrees. Results revealed that thiamine helped in the remote germination; seeds of Anaj 2017 germinated within 16 hours while Akbar 2019 germinated after one day. Overall growth parameters of Anaj 2017 were negatively affected even under higher levels of drought stress, while Akbar 2019 proved to be a susceptible cultivar. A significant increase in RFW (54\%), SFW (85\%), RDW (69\%), SDW (67\%) and TChl (136\%) validated the effectiveness of D-T3 compared to C-T0 in drought stress. Significant decrease in MDA, EL and $\mathrm{H}_{2} \mathrm{O}_{2}$ signified the imperative function of D-T3 over C-T0 under drought stress. In conclusion and recommendation, we declare that farmers can get better wheat growth under drought stress by application of D-T3 over C-T0.

Keywords: drought; physiological attributes; growth attributes; antioxidants; wheat; thiamine; endophytic bacteria

\section{Introduction}

Among all abiotic stresses (heavy metals [1-6], salinity [7], nutrient deficiency [8,9]), drought is the most severe stress [10] that decreases crop production in various world climatic regions [11,12]. A drastic reduction (50\%) in the yield of crops occurs annually due to soil water deficiencies $[11,13]$. Dry winds, high light intensity, shifts in monsoon patterns, physiological drought conditions (salinity stress) and temperature dynamics are reasons for water scarcity in any region. Such factors result in extensive evapotranspiration, water holding capacity of the rhizosphere and uneven or low rainfall patterns [11,13]. Continuous greenhouse gas emissions also increase earth temperature by trapping heat [14]. Further- 
more, higher levels of atmospheric $\mathrm{CO}_{2}$, deforestation, industrialization and urbanization are allied factors that facilitate drought stress development.

Less fertilizer application can reduce production costs [15] as well as emissions of $\mathrm{CO}_{2}$ and nitrogen oxides to the atmosphere [16]. Very scarce data is present concerning water relations in wheat inoculated with diazotrophic bacteria under water deficit conditions regarding mineral contents and yield [17]. Seeds are frequently used in agricultural practices due to their storage capacity, tolerance to physical agents and low effort to manageability $[18,19]$. Different fluctuations and microorganisms in the rhizosphere constantly challenge plants. Several rhizobia microorganisms establish beneficial associations with plant root surfaces or make endosymbiotic associations [20]. The diazotrophic bacterial association is an effective alternative to chemical $\mathrm{N}$-fertilizers and the environmental contamination caused by fertilizer use [20].

Typical chemical communication is developed between bacteria in the rhizosphere and the roots of the host plant. This symbiotic association increases plant biomass, height, dry weight, root length yield and, most importantly, induction of tolerance to both biotic and abiotic stress factors [20]. Bacterial inoculated wheat plants are reported to have a more extensive root system. Root mass is increased by $30 \%$ in colonized roots relative to non-inoculated plants [16]. The beneficial output by bacterial association with roots is greatly affected by plant physiological state and other stress factors present in the environment [20]. Considering rhizosphere-endophytes-plant as a unit coordinating with dynamically changing rhizosphere environments and then integrating them to induce tolerance and adaptive responses against different stresses, i.e., abiotic and biotic, improves growth and nutrient uptake [20].

On the other hand, thiamin (vitamin B1) is an imperative participant of the vitamin B group and shows a key role in mitigating drought stress. Typically, drought stress is linked with yellowing of leaves, leaf curling, stunted growth, leaf senescence and permanent wilting. At $50 \%$ field capacity (FC), ascorbic acid, total phenolic and biomass yield in particular are reduced [21]. To cope with drought stress, plants have extensive roots with the deep, elongated capillary structure to uptake more water from deeper layers [22]. Solute accumulation during osmotic adjustment, antioxidant defense system and stomatal closure dynamics are other strategies that plants adopt during less availability of water [11]. At the same time, stress-related contents like hydrogen peroxide $\left(\mathrm{H}_{2} \mathrm{O}_{2}\right)$, glycine betaine (GB), malondialdehyde (MDA), proline, superoxide dismutase (SOD), peroxidase (POD) and catalase (CAT) contents were enhanced significantly [21]. Seed soaking in vitamin B1 has a favorable effect on the accumulation of valuable ions and is proven to ameliorate the inhibitory effect of abiotic stress. Exogenously applied thiamin is reported to improve all growth attributes, photosynthetic pigments, pigments biosynthesis, osmoprotectants in leaves and roots, membrane integrity and increased enzymatic antioxidants, i.e., SOD, POD and $\mathrm{CAT}$, ascorbic acid constituents, and total phenolics in drought stress conditions. $\mathrm{K}^{+}$ leakage was reduced by the application of thiamine (B1). Thiamin treatment significantly increases proline and glycine betaine contents and decreases malondialdehyde (MDA) and hydrogen peroxide $\left(\mathrm{H}_{2} \mathrm{O}_{2}\right)$ even at $50 \%$ field capacity. Thiamin treatment plays an essential role in declining different reactive oxygen species (ROS) under drought conditions and induces tolerance in plants [21,23].

Among food crops, wheat is the most cultivated cereal grain. Pakistan is one of the 10 major contributors to wheat [24]. The collectively $12 \mathrm{M}$ ha. cultivated area of Pakistan is cropped by wheat and rice, contributing $50-60 \%$ per capita daily caloric intake [25]. As a staple food crop of Pakistan, wheat (Triticum aestivum L.) has $2.78 \mathrm{t} \mathrm{ha}^{-1}$ per year production which is now facing $0.33 \mathrm{t} \mathrm{ha}^{-1}$ losses compared to mean yields due to drought stress stresses [26]. That is why the current study was conducted to explore the improvement in the effectiveness of bacterial inoculation with thiamine by selecting the best thiamine application rate for alleviating. It is hypothesized that diazotrophic bacteria inoculation with the pre-sowing application of thiamine can mitigate drought stress more effectively in wheat than sole inoculation. 


\section{Materials and Methods}

\subsection{Seeds Sterilization}

Seeds of two genotypes (Akbar 2019 and Anaj 2017) of wheat (Triticum aestivum L.) were disinfected using sodium hypochlorite solution washing with distilled water. Then the seeds were soaked in solution supplemented with thiamine for $24 \mathrm{~h}$.

\subsection{Seeds Inoculation and Transplantation}

A total of 10 seeds from each treatment were distributed in petri plates on Whatman filter paper no. 1, moistened with $10 \mathrm{~mL}$ each of the respective treatment solution. To maintain moisture levels, plates were covered with Parafilm for the first five days and incubated. Emerging seedlings remained in petri plates for 10 days. After this, the seedling roots were inoculated with bacteria. Bacillus strain RH-5 (gram-positive, facultative aerobic endospore-forming bacteria) was used. For inoculation in roots, bacteria were cultured in Luria-Bertani (LB) agar plate's solution at $37^{\circ} \mathrm{C}$ temperatures. Bacterial cells were re-suspended in sterile $0.9 \% \mathrm{NaCl}$ solution after centrifugation at a concentration of $10^{7}$ colonies forming unit (CFU) to prepare bacterial culture. Then seedlings were shifted to pots containing soil.

\subsection{Experimental Design}

The pots were settled at a completely randomized design (CRD) with four replicates and two genotypes of wheat (Triticum aestivum L.), Akbar (2019) and Anaj (2017), at the laboratory of plant physiology, Department of Botany, University of Agriculture Faisalabad Punjab Pakistan.

\subsection{Treatment Plan}

There were four levels of thiamine for both genotypes: pre-sowing treatment with 0, (no thiamin, control), 50, 100 and $150 \mathrm{ppm}$ in thiamin supplemented solution for $24 \mathrm{~h}$. The treatments include control with bacteria and no thiamine $+35 \%$ FC (C-T0), 50 ppm thiamine + bacteria + 35\% FC (D-T1), 100 ppm thiamine + bacteria + 35\% FC (D-T2) and 150 ppm thiamine + bacteria $+35 \%$ FC (D-T3).

\subsection{Drought Stress}

The soil moisture level was maintained at 35\% FC levels on $w / w$ basis. The water requirement was maintained by using tap water for irrigation on daily basis.

\subsection{Harvesting and Data Collection}

The plants were harvested after 20 days of transfer to soil media. Their morphological, physiological and biochemical parameters were characterized. All chemicals used in this experiment were of analytical grades.

\subsection{Physiological Attributes}

Plants were washed with distilled water. Fully functional leaves from each treatment were selected for various pigment and enzymatic content studies. Lengths of root and shoot, dry and fresh weights, chlorophyll (Chl) a, Chl b, total Chl, carotenoids, glycine betaine, proline, total soluble proteins, $\mathrm{MDA}, \mathrm{H}_{2} \mathrm{O}_{2}$, electrolyte leakage and contents like catalyze, phenolics, ascorbic acid, anthocyanin, soluble sugars and flavonoids were measured in both root and shoot. Analysis of ions like sodium, calcium, potassium and phosphorus was also evaluated.

Plant shoot and root lengths were measured using a measuring tape. Their fresh weights were measured using a digital weighing balance immediately after harvesting. Plant samples were stored at $30^{\circ} \mathrm{C}$ fresh analysis. Plants from every treatment were washed and oven dehydrated for $72 \mathrm{~h}$ at $65{ }^{\circ} \mathrm{C}$. These dried samples were used for dry weight measurement, same as fresh weight measurements. Chlorophyll (Chl) a, b, carotenoids and total chlorophyll were measured following standard Arnon protocol [27]. The $0.1 \mathrm{~g}$ fresh 
leaf samples were extracted in $95 \%$ acetone $(8 \mathrm{~mL})$ at $4 \mathrm{C}$ in the dark for $24 \mathrm{~h}$. Absorbance of 646.6, 663.6 and $450 \mathrm{~nm}$ was measured using a spectrophotometer (UV-2550; Shimadzu, Kyoto, Japan).

\subsection{Oxidative Stress Indicators}

Malondialdehyde (MDA) contents were evaluated to find the extent of lipid peroxidation. A weight of $0.1 \mathrm{~g}$ of fresh leaf samples was ground at $4{ }^{\circ} \mathrm{C}$ in $50 \mathrm{mM}$ phosphate buffer solution $(25 \mathrm{~mL}, \mathrm{pH} 7.8)$, having $1 \%$ polyethene pyrrole. This homogenous mixture was centrifuged at $4{ }^{\circ} \mathrm{C}$ for $15 \mathrm{~min}$ at $10,000 \mathrm{rpm}$. The mixture was heated at $100{ }^{\circ} \mathrm{C}$ for $20 \mathrm{~min}$ and immediately cooled using an ice bath. The absorbance of supernatant liquid was recorded using a spectrophotometer (xMark, Microplate Absorbance Spectrophotometer; Bio-Rad, Hercules, CA, USA) at 532, 600 and $450 \mathrm{~nm}$ wavelengths. Peroxidation of lipids was expressed as $1 \mathrm{~mol} \mathrm{~g}^{-1}$ by the formula: 6.45 (A532 - A600) - 0.56 A450) using protocol by Heath and Packer, previously published [28]. Estimation of $\mathrm{H}_{2} \mathrm{O}_{2}$ content of root and leaf samples was done by taking $3 \mathrm{~mL}$ sample extract mixed with $1 \mathrm{~mL} 0.1 \%$ titanium sulfate in $20 \% \mathrm{H}_{2} \mathrm{SO}_{4}(\mathrm{v} / \mathrm{v})$ and then centrifuged at $6000 \mathrm{rpm}$ for about $15 \mathrm{~min}$. The yellow color intensity of samples was evaluated using a spectrophotometer at $410 \mathrm{~nm}$ wavelength $\mathrm{H}_{2} \mathrm{O}_{2}$ levels were assessed by $0.28 \mathrm{mmol}^{-1} \mathrm{~cm}^{-1}$ extinction coefficient, following the method of Jana and Choudhuri [29].

\subsection{Electrolyte Leakage}

Electrolyte leakage (EL) induced by the stress of flag leaves was evaluated by using the protocol given by Dionisio-Sese and Tobita [30]. The leaves were cut into small pieces and immersed in $8 \mathrm{~mL}$ distilled water in test tubes. The test tubes were incubated in the water bath for $2 \mathrm{~h}$ before measuring initial electrical conductivity (EC 1). Extracts were autoclaved at $121^{\circ} \mathrm{C}$ for $20 \mathrm{~min}$ and cooled down at room temperature before measuring final electrical conductivity (EC 2), calculated by the following formula;

$$
\operatorname{EL}(\%)=(E C 1 / E C 2)-100
$$

\subsection{Antioxidant Enzymes Activities}

Peroxidase activity in wheat leaves was analyzed by Sakharov and Ardila [31] method by using guaiacol substrate. A total of $3 \mathrm{~mL}$ of reaction mixture was prepared that contained $0.05 \mathrm{~mL}$ enzyme extract, $50 \mathrm{mM}$ phosphate buffer (2.75 mL, pH 7.0), $0.1 \mathrm{~mL} 1 \% \mathrm{H}_{2} \mathrm{O}_{2}$, and $0.1 \mathrm{~mL} 4 \%$ guaiacol solution. Absorbance was recorded at $470 \mathrm{~nm}$. The unit enzyme activity was considered as the amount of the enzyme present.

Catalase enzyme activity was determined according to the Aebi method [32]. A quantity of $3.0 \mathrm{~mL}$ of the reaction mixture was comprised of enzyme extract $(100 \mathrm{~L}), \mathrm{H}_{2} \mathrm{O}_{2}(100 \mathrm{~L}$, $300 \mathrm{mM}$ ), and phosphate buffer (2.8 mL $50 \mathrm{mM}$ ) with ETDA (2 mM, pH 7.0). Due to $\mathrm{H}_{2} \mathrm{O}_{2}$ loss, the CAT activity was measured at 240 by a decline in absorbance.

\subsection{Estimation of Proline, Sugars and Non-Enzymatic Antioxidants}

To determine osmolytes and non-enzymatic antioxidants, ethanol extracts of plant samples were prepared using a $50 \mathrm{mg}$ dry plant homogenized in $10 \mathrm{~mL}$ of $80 \%$ ethanol. The solution was filtered through filter paper (Whatman No. 41) followed by re-extraction in ethanol. The final volume of $20 \mathrm{~mL}$ was maintained by mixing the two extracts, and the reaction mixture was used to determine anthocyanin [33], phenolics [34], flavonoids [35], total sugars [36] and ascorbic acid [37] contents.

\subsection{Statistical Analysis}

The data obtained was tested with a two-way ANOVA difference (ANOVA) difference in treatments. Mean comparison between treatments was made using the least significant difference test $(p<0.05)$ [38]. Logarithmic or inverse transformations were performed for data normalization, where necessary, before analysis. Pearson's correlation analysis was 
implemented to compute associations among various analyzed variables. The graphical demonstration was carried out by using Origin 2021 [39]. The Pearson correlation (heatmap) conceits between the measured variables were also calculated using Python software.

\section{Results}

Effects of treatments were significant in root fresh weight (RFW), shoot fresh weight (SFW), root dry weight (RDW), shoot dry weight (SDW), root length (RL) and shoot length (SL) of Akbar 19 and Anaj 17. Treatment D-T3 was significantly best for the improvement in RFW of Akbar 19 over C-T0. Application of D-T2 and D-T1 also performed significantly better for RFW than C-T0 in Akbar 19. In the case of Anaj 17, D-T3 and D-T2 were statistically alike but differed significantly compared to C-T0. Treatment D-T1 remained significantly better over C-T0 for RFW of Anaj 17 (Figure 1A). On average, D-T3 caused a maximum increase (54\%) in RFW over C-T0. However, Akbar 19 showed 24\% significantly higher RFW over Anaj 17 (Table 1). For SFW, D-T3 remained significantly better than C-T0 in Akbar 19 and Anaj 17. Application of D-T2 and D-T1 also significantly increased SFW in Akbar 19. In Anaj 17, D-T2 differed significantly, but D-T1 did not remain significant for SFW over C-T0 (Figure 1B). On average, D-T3 caused a maximum increase (85\%) in SFW over C-T0. However, Anaj 17 showed 60\% significantly higher SFW over Akbar 19 (Table 1). The addition of D-T3 significantly enhanced RDW in Akbar 19 and Anaj 17 than C-T0. Treatments D-T2 and D-T1 also significantly improved RDW in Akbar 19 and Anaj 17 over C-T0 (Figure 1C). On average, D-T3 caused a maximum increase (69\%) in RDW over C-T0. However, Anaj 17 showed 41\% significantly higher RDW over Akbar 19 (Table 1). No significant change was noted in SDW where D-T3 and D-T2 were applied in Akbar 19. However, both D-T3 and D-T2 differed significantly over C-T0 for SDW in Akbar 19. Treatments C-T0 and D-T1 were statistically alike to each other for SDW in Akbar 19. For Anaj 17, a significant increase in SDW (Figure 1D), SL (Figure 1F) but a decrease in root length (Figure 1E) was observed in D-T3, D-T2 and D-T1 compared to C-T0. On average, C-T0 caused a maximum increase in RL and SL over D-T3. For SDW, D-T3 application cause 67\% significant increase over C-T0. However, Akbar 19 showed $50 \%$ and 51\% significantly higher RL and SL over Anaj 17, respectively (Table 1).

Table 1. Main effect of treatments and varieties on RFW, SFW, RDW, SDW, RL and SL.

\begin{tabular}{ccccccc}
\hline \multirow{2}{*}{ Treatment } & \multicolumn{7}{c}{ Main Effect of Treatments } \\
\cline { 2 - 7 } & RFW (g) & SFW (g) & RDW (g) & SDW (g) & RL (cm) & SL (cm) \\
\hline C-T0 & $2.14 \mathrm{~d}$ & $0.88 \mathrm{~b}$ & $0.35 \mathrm{c}$ & $0.85 \mathrm{~d}$ & $1.48 \mathrm{a}$ & $3.20 \mathrm{a}$ \\
\hline D-T1 & $2.52 \mathrm{c}$ & $0.96 \mathrm{~b}$ & $0.42 \mathrm{~b}$ & $1.01 \mathrm{c}$ & $1.10 \mathrm{~b}$ & $2.46 \mathrm{~b}$ \\
\hline D-T2 & $2.97 \mathrm{~b}$ & $1.54 \mathrm{a}$ & $0.42 \mathrm{~b}$ & $1.29 \mathrm{~b}$ & $1.00 \mathrm{~b}$ & $1.95 \mathrm{c}$ \\
\hline D-T3 & $3.30 \mathrm{a}$ & $1.63 \mathrm{a}$ & $0.59 \mathrm{a}$ & $1.42 \mathrm{a}$ & $0.53 \mathrm{c}$ & $0.89 \mathrm{~d}$ \\
\hline Variety & & Main Effect of Variety & & \\
\hline Akbar 19 & $3.03 \mathrm{a}$ & $0.96 \mathrm{~b}$ & $0.37 \mathrm{~b}$ & $0.83 \mathrm{~b}$ & $1.23 \mathrm{a}$ & $2.54 \mathrm{a}$ \\
\hline Anaj 17 & $2.44 \mathrm{~b}$ & $1.54 \mathrm{a}$ & $0.52 \mathrm{a}$ & $1.46 \mathrm{a}$ & $0.82 \mathrm{~b}$ & $1.70 \mathrm{~b}$ \\
\hline & & ANOVA & & \\
\hline $\begin{array}{c}\text { Grand } \\
\text { Mean }\end{array}$ & 2.73 & 1.25 & 0.44 & 1.14 & 1.03 & 2.12 \\
\hline CV & 5.47 & 7.65 & 6.89 & 10.94 & 17.39 & 7.12 \\
\hline
\end{tabular}

Different letters showed a significant difference at $p \leq 0.05$. Root Fresh Weight (RFW), Shoot Fresh Weight (SFW), Root Dry Weight (RDW), Shoot Dry Weight (SDW), Root Length (RL) and Shoot Length (SL). 

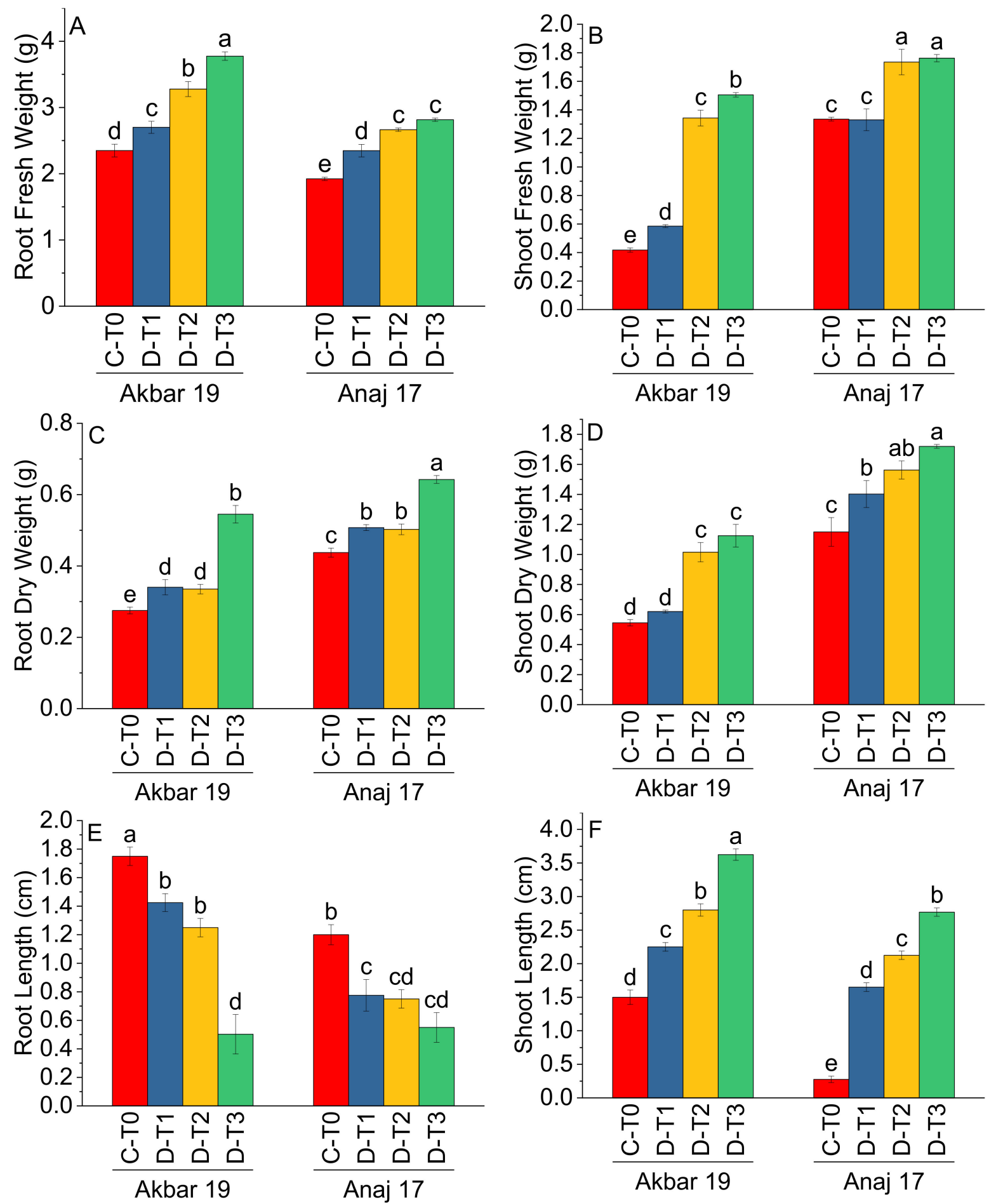

Figure 1. Effect of different application rates of thiamine in the presence of bacteria on growth attributes of two wheat cultivars (Akbar 19 and Anaj 17) under severe drought stress (35\%FC). Different values on bars showed significant difference at $p \leq 0.05$; LSD test. $(\mathbf{A})=$ root fresh weight; $(\mathbf{B})=$ shoot fresh weight; $(\mathbf{C})=$ root dry weight; $(\mathbf{D})=$ shoot dry weight; $(\mathrm{E})=$ root length; $(\mathbf{F})=$ shoot length.

A significant change was noted in chlorophyll a (Chla), chlorophyll b (Chlb), total chlorophyll (TChl), carotenoids (Ca), catalase root (CR) and catalase (CS) of Akbar 19 and Anaj 17 by the application of treatments. The addition of D-T3 was significantly different for enhancement in Chla of Akbar 19 and Anaj 17 over C-T0. Application of D-T2 and D-T1 also differed significantly for Chla than C-T0 in Akbar 19 but remained non-significant in 
Anaj 17. (Figure 2A). On average, D-T3 caused a maximum increase (166\%) in Chla over C-T0. However, Akbar 19 showed 18\% significantly higher Chla over Anaj 17 (Table 2). For Chlb, D-T3 remained significantly better than C-T0 in Anaj 17. Application of D-T2 and D-T1 were non-significant in Anaj 17 for Chlb. In Akbar 19, all the treatments remained non-significant for Chlb over C-T0 (Figure 2B). On average, D-T3 caused a maximum increase (86\%) in Chlb over C-T0. However, Akbar 19 showed 41\% significantly higher Chlb over Anaj 17 (Table 2). The addition of D-T3 significantly enhanced TChl in Akbar 19 and Anaj 17 over C-T0. Treatments D-T2 and D-T1 were significantly different for TChl in Akbar 19 but remained non-significant in Anaj 17 over C-T0 (Figure 2C). On average, D-T3 caused a maximum increase (136\%) in TChl over C-T0. However, Akbar 19 showed $1.9 \%$ significantly higher TChl over Anaj 17 (Table 2). A significant decrease was noted in CATR (Figure 2E) and CATS (Figure 2F), where D-T3 and D-T2 were applied over C-T0 in Akbar 19 and Anaj 17. On average, C-T0 caused a maximum increase in CATR (70\%) and CATS (54\%) over D-T3. For CATR, D-T3 application causes a significant increase over C-T0. However, Akbar 19 showed 8.4\% significantly higher CATR over Anaj 17 (Table 2).

Table 2. Main effect of treatments and varieties on Chla, Chlb, TChl, Ca, CATR and CATS.

\begin{tabular}{ccccccc}
\hline \multirow{2}{*}{ Treatment } & \multicolumn{5}{c}{ Main Effect of Treatments } \\
\cline { 2 - 7 } & $\begin{array}{c}\text { Chla } \\
(\mathbf{m g} / \mathbf{g})\end{array}$ & $\begin{array}{c}\text { Chlb } \\
(\mathbf{m g} / \mathbf{g})\end{array}$ & $\begin{array}{c}\text { TChl } \\
(\mathbf{m g} / \mathbf{g})\end{array}$ & Ca $(\mathbf{m g} / \mathbf{g})$ & CATR & CATS \\
\hline C-T0 & $0.78 \mathrm{c}$ & $0.51 \mathrm{~b}$ & $1.29 \mathrm{c}$ & $0.036 \mathrm{c}$ & $1.39 \mathrm{a}$ & $1.43 \mathrm{a}$ \\
\hline D-T1 & $1.50 \mathrm{~b}$ & $0.51 \mathrm{~b}$ & $2.02 \mathrm{~b}$ & $0.055 \mathrm{bc}$ & $1.50 \mathrm{~b}$ & $1.27 \mathrm{~b}$ \\
\hline D-T2 & $1.61 \mathrm{~b}$ & $0.62 \mathrm{~b}$ & $2.23 \mathrm{~b}$ & $0.067 \mathrm{~b}$ & $1.11 \mathrm{~b}$ & $1.12 \mathrm{c}$ \\
\hline D-T3 & $2.08 \mathrm{a}$ & $0.95 \mathrm{a}$ & $3.04 \mathrm{a}$ & $0.103 \mathrm{a}$ & $0.82 \mathrm{c}$ & $0.93 \mathrm{~d}$ \\
\hline Variety & & & Main Effect of Variety & & \\
\hline Akbar 19 & $1.62 \mathrm{a}$ & $0.54 \mathrm{~b}$ & $2.16 \mathrm{a}$ & $0.070 \mathrm{a}$ & $1.16 \mathrm{a}$ & $1.62 \mathrm{a}$ \\
\hline Anaj 17 & $1.37 \mathrm{a}$ & $0.76 \mathrm{a}$ & $2.12 \mathrm{a}$ & $0.060 \mathrm{a}$ & $1.07 \mathrm{~b}$ & $1.21 \mathrm{a}$ \\
\hline Grand & 1.50 & 0.65 & ANOVA & & \\
\hline Mean & 25.05 & 39.65 & 16.18 & 29.29 & 8.09 & 7.33 \\
\hline CV & & & & & \\
\hline
\end{tabular}

Different letters showed a significant difference at $p \leq 0.05$. Chlorophyll a (Chla), Chlorophyll b (Chlb), Total Chlorophyll (TChl), Carotenoids (Ca), Catalase root (CATR) and Catalase (CATS).

Results showed that treatments significantly affected the malondialdehyde (MDA), hydrogen peroxide $\left(\mathrm{H}_{2} \mathrm{O}_{2}\right)$, electrolyte leakage (EL), total soluble proteins (TSP), soluble sugar in the root (SSR) and soluble sugar in the shoot (SSS) of Akbar 19 and Anaj 17. In MDA, D-T3, D-T2 and D-T1 caused a significant decrease over C-T0 in Akbar 19 and Anaj 17 (Figure 3A). Treatments D-T3 and D-T2 significantly decreased $\mathrm{H}_{2} \mathrm{O}_{2}$ over C-T0 in Akbar 19 and Anaj 17 (Figure 2B). A significant decrease was noted in EL (Figure 3C), SSR (Figure 2E) and SSS (Figure 3F), where D-T3 and D-T2 were applied over C-T0 in Akbar 19 and Anaj 17. However, D-T3 and D-T2 significantly enhanced TSP over C-T0 in Akbar 19 and Anaj 17. No significant change was noted in TSP where D-T1 was applied over C-T0 in Akbar 19 and Anaj 17 (Figure 3D). On average, C-T0 caused a maximum increase in MDA $(193 \%), \mathrm{H}_{2} \mathrm{O}_{2}(114 \%)$, EL (99\%), over D-T3. However, Anaj 17 showed significantly higher MDA (53\%), $\mathrm{H}_{2} \mathrm{O}_{2}(18 \%)$, EL (96\%) and SSS (9.60\%) over Akbar 19 (Table 3). 

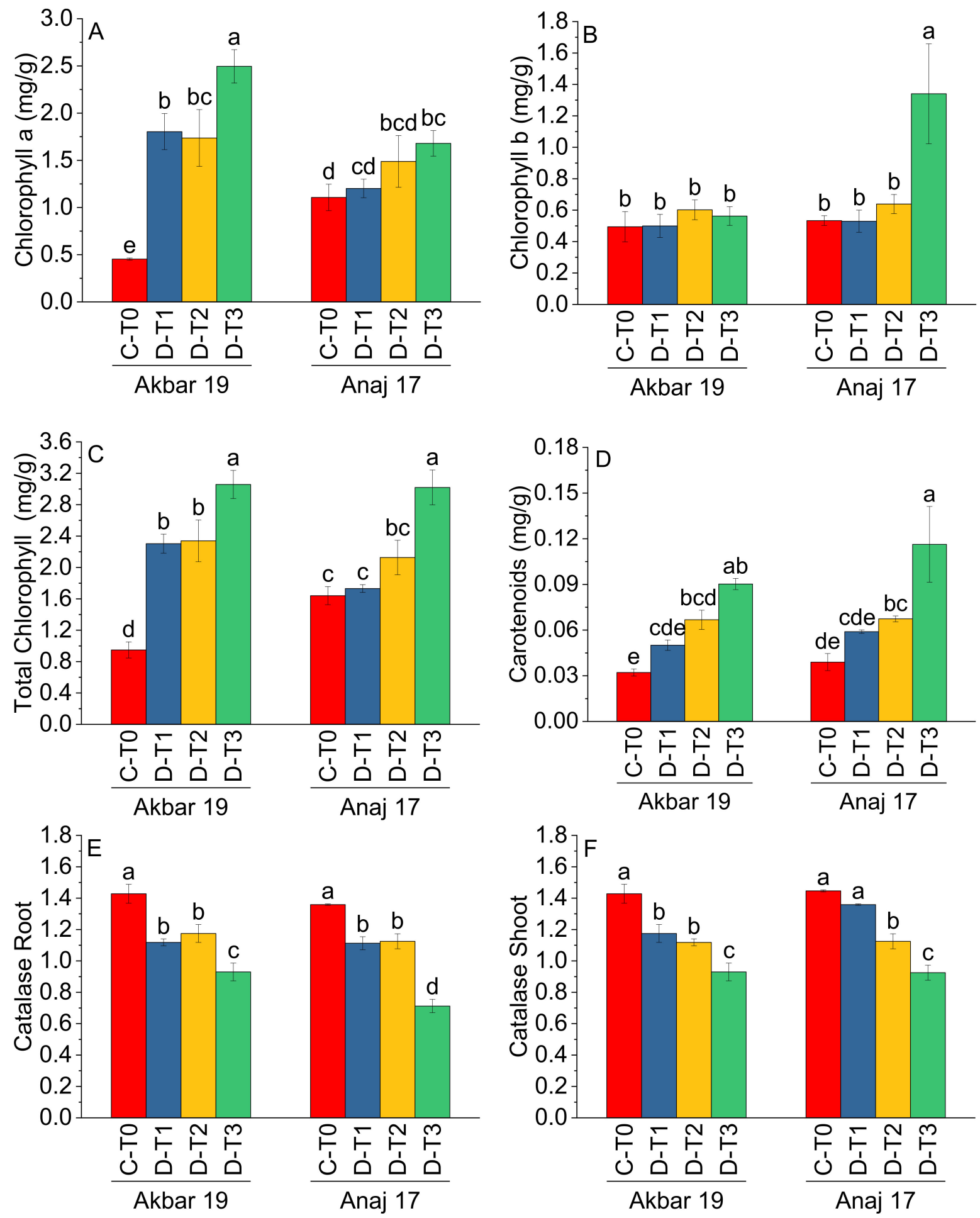

Figure 2. Effect of different application rates of thiamine in the presence of bacteria on chlorophyll contents, carotenoids and catalase (root and shoot) of two wheat cultivars (Akbar 19 and Anaj 17) under severe drought stress (35\%FC). Different values on bars showed significant difference at $p \leq 0.05$; LSD test. $(\mathbf{A})=$ chlorophyll $\mathrm{a} ;(\mathbf{B})=\operatorname{chlorophyll} \mathrm{b} ;(\mathbf{C})=$ total chlorophyll; $(\mathbf{D})=$ carotenoids; $(\mathrm{E})=$ catalase $\operatorname{root} ;(\mathrm{F})=$ catalase shoot. 

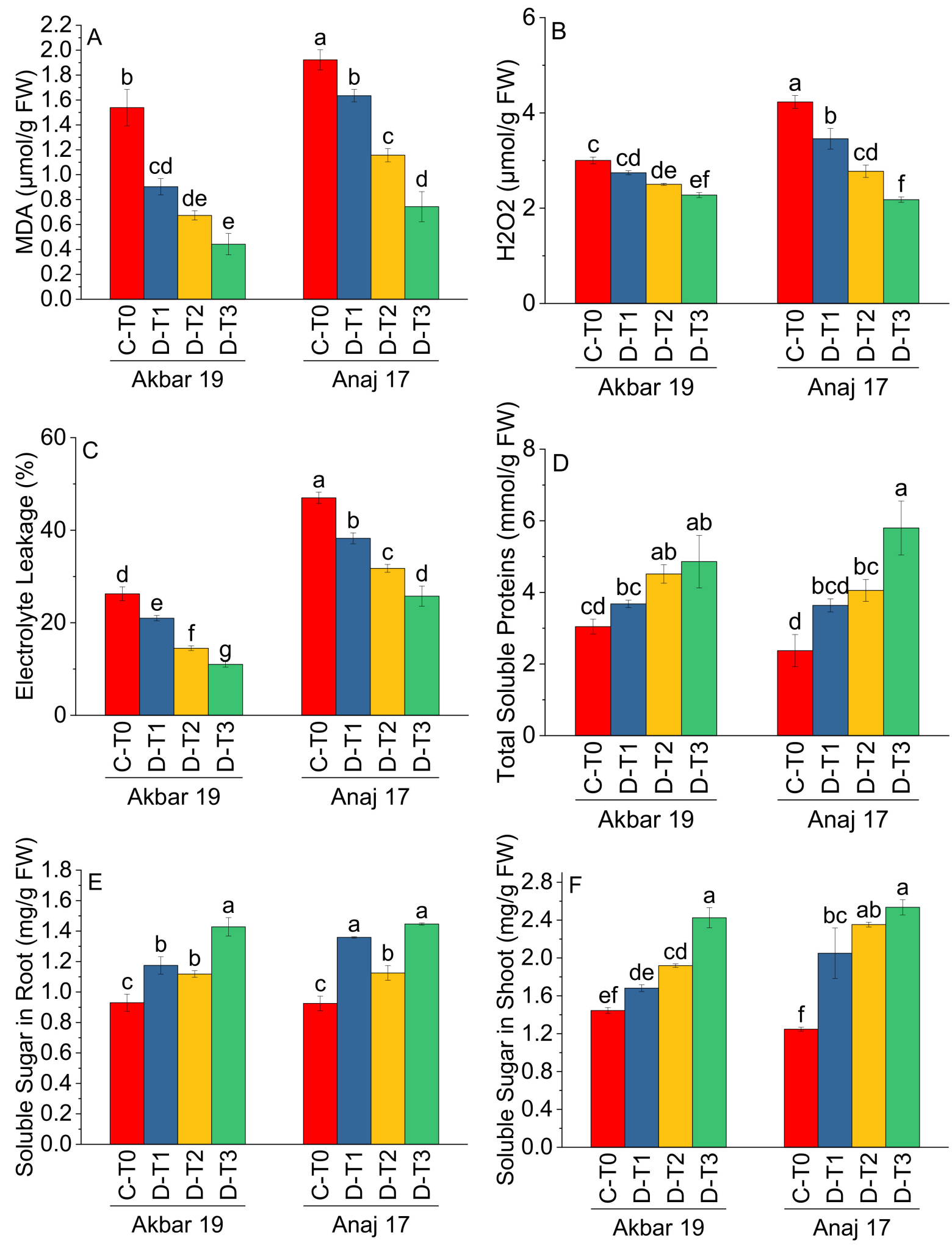

Figure 3. Effect of different application rates of thiamine in the presence of bacteria on antioxidants, electrolyte leakage, total soluble protein and soluble sugar (root and shoot) of two wheat cultivars (Akbar 19 and Anaj 17) under severe drought stress (35\%FC). Different values on bars showed significant difference at $p \leq 0.05$; LSD test. (A) = malondialdehyde; $(\mathbf{B})=$ hydrogen peroxide; $(\mathbf{C})=$ electrolyte leakage; $(\mathbf{D})=$ total soluble proteins; $(\mathbf{E})=$ soluble sugar in the root; $(\mathbf{F})=$ soluble sugar in the shoot. 
Table 3. Main effect of treatments and varieties on MDA, $\mathrm{H}_{2} \mathrm{O}_{2}, \mathrm{EL}, \mathrm{TSP}, \mathrm{SSR}$ and SSS.

\begin{tabular}{|c|c|c|c|c|c|c|}
\hline \multirow{2}{*}{ Treatment } & \multicolumn{6}{|c|}{ Main Effect of Treatments } \\
\hline & $\begin{array}{c}\text { MDA }(\mu \mathrm{mol} / \mathrm{g} \\
\text { FW) }\end{array}$ & $\begin{array}{c}\mathrm{H}_{2} \mathrm{O}_{2} \\
(\mu \mathrm{mol} / \mathrm{g} \mathrm{FW})\end{array}$ & $\begin{array}{c}\text { EL } \\
(\%)\end{array}$ & $\begin{array}{c}\text { TSP } \\
(\mathrm{mmol} / \mathrm{g} \text { FW) }\end{array}$ & $\begin{array}{c}\text { SSR } \\
(\mathrm{mg} / \mathrm{g} \text { FW) }\end{array}$ & $\begin{array}{c}\text { SSS } \\
(\mathrm{mg} / \mathrm{g} \text { FW) }\end{array}$ \\
\hline C-T0 & $1.73 \mathrm{a}$ & $3.61 \mathrm{a}$ & $36.62 \mathrm{a}$ & $2.71 \mathrm{c}$ & $0.93 \mathrm{~d}$ & $1.34 \mathrm{~d}$ \\
\hline D-T1 & $1.27 \mathrm{~b}$ & $3.10 \mathrm{~b}$ & $29.62 b$ & $3.66 \mathrm{~b}$ & $1.12 \mathrm{c}$ & $1.87 \mathrm{c}$ \\
\hline D-T2 & $0.91 \mathrm{c}$ & $2.64 \mathrm{c}$ & $23.13 c$ & $4.29 \mathrm{~b}$ & $1.27 \mathrm{~b}$ & $2.14 \mathrm{~b}$ \\
\hline D-T3 & $0.59 \mathrm{~d}$ & $2.23 \mathrm{~d}$ & $18.38 \mathrm{~d}$ & $5.32 \mathrm{a}$ & $1.44 \mathrm{a}$ & $2.48 \mathrm{a}$ \\
\hline Variety & \multicolumn{6}{|c|}{ Main Effect of Variety } \\
\hline Akbar 19 & $0.89 \mathrm{~b}$ & $2.63 \mathrm{~b}$ & $18.18 \mathrm{~b}$ & $4.02 \mathrm{a}$ & $1.16 \mathrm{a}$ & $1.87 \mathrm{~b}$ \\
\hline Anaj 17 & $1.36 \mathrm{a}$ & $3.16 \mathrm{a}$ & $35.68 \mathrm{a}$ & $3.97 \mathrm{a}$ & $1.21 \mathrm{a}$ & $2.05 \mathrm{a}$ \\
\hline \multicolumn{7}{|c|}{ ANOVA } \\
\hline Grand Mean & 1.13 & 2.89 & 26.99 & 4.00 & 1.19 & 1.96 \\
\hline $\mathrm{CV}$ & 15.48 & 7.50 & 8.90 & 22.03 & 7.33 & 11.00 \\
\hline
\end{tabular}

Different letters showed a significant difference at $p \leq 0.05$. Malondialdehyde (MDA), Hydrogen Peroxide $\left(\mathrm{H}_{2} \mathrm{O}_{2}\right)$, Electrolyte Leakage (EL), Total Soluble Proteins (TSP), Soluble Sugar in Root (SSR) and Soluble Sugar in Shoot (SSS).

Effect of treatments was significant for anthocyanin in the root (AR), anthocyanin in the shoot (AS), flavonoids in the root (FR), flavonoids in the root (FS), ascorbic acid (AsA) and phenolics (Phe) of Akbar 19 and Anaj 17. For AR (Figure 4A), AS (Figure 4B), FR (Figure 4C), FS (Figure 4D), AsA (Figure 4E) and Phe (Figure 4F), treatments D-T3 and D-T2 caused a significant decrease over C-T0 in Akbar 19 and Anaj 17. Application of D-T1 was non-significant over C-T0 in Akbar 19 and Anaj 17 for AR and AsA. However, D-T1 differed significantly over C-T0 in Akbar 19 and Anaj 17 for AS, FR and P. On average, C-T0 caused a maximum increase in AnthR (81\%), AnthS (114\%), FR (83\%), FS (89\%), AsA (82\%) and Phe (149\%) over D3-T3. However, Anaj 17 showed significantly higher AnthR (148\%), AsA (33\%) and Phe (42\%) over Akbar 19. For FR, Akbar 19 significantly increased (17\%) over Anaj 17 (Table 4). Pearson correlation showed the significant and non-significant correlation of attributes in Figure 5.

Table 4. Main effect of treatments and varieties on AnthR, AnthS, FR, FFS, AsA and Phe.

\begin{tabular}{|c|c|c|c|c|c|c|}
\hline \multirow{2}{*}{ Treatment } & \multicolumn{6}{|c|}{ Main Effect of Treatments } \\
\hline & $\begin{array}{c}\text { AnthR } \\
(\mu \mathrm{g} / \mathrm{g} \text { FW })\end{array}$ & $\begin{array}{c}\text { AnthS } \\
(\mu \mathrm{g} / \mathrm{g} \text { FW })\end{array}$ & $\begin{array}{c}\text { FR } \\
(\mu \mathrm{g} / \mathrm{g} \text { FW })\end{array}$ & $\begin{array}{c}\text { FS } \\
(\mu \mathrm{g} / \mathrm{g} \text { FW })\end{array}$ & $\begin{array}{c}\text { AsA } \\
\text { (mg/g FW) }\end{array}$ & $\begin{array}{c}\text { Phe } \\
\text { (mg/g FW) }\end{array}$ \\
\hline C-T0 & $1.21 \mathrm{a}$ & $1.22 \mathrm{a}$ & $1.06 \mathrm{a}$ & $1.06 \mathrm{a}$ & $36.00 \mathrm{a}$ & $3.61 \mathrm{a}$ \\
\hline D-T1 & $1.08 \mathrm{~b}$ & $0.88 \mathrm{~b}$ & $0.76 \mathrm{~b}$ & $0.84 \mathrm{~b}$ & $31.38 \mathrm{~b}$ & $2.38 \mathrm{~b}$ \\
\hline D-T2 & $0.93 \mathrm{c}$ & $0.74 \mathrm{c}$ & $0.67 \mathrm{bc}$ & $0.68 \mathrm{c}$ & $25.88 \mathrm{c}$ & $1.96 \mathrm{bc}$ \\
\hline D-T3 & $0.67 \mathrm{~d}$ & $0.57 \mathrm{~d}$ & $0.58 \mathrm{c}$ & $0.56 \mathrm{~d}$ & $19.75 \mathrm{~d}$ & $1.45 \mathrm{c}$ \\
\hline Variety & \multicolumn{6}{|c|}{ Main Effect of Variety } \\
\hline Akbar 19 & $0.56 \mathrm{~b}$ & $0.81 \mathrm{a}$ & $0.83 \mathrm{a}$ & $0.78 \mathrm{a}$ & $24.25 \mathrm{~b}$ & $1.95 \mathrm{~b}$ \\
\hline Anaj 17 & $1.39 \mathrm{a}$ & $0.89 \mathrm{a}$ & $0.71 \mathrm{~b}$ & $0.79 \mathrm{a}$ & $32.25 \mathrm{a}$ & $2.76 \mathrm{a}$ \\
\hline \multicolumn{7}{|c|}{ ANOVA } \\
\hline Grand Mean & 0.97 & 0.85 & 0.77 & 0.78 & 28.25 & 2.35 \\
\hline $\mathrm{CV}$ & 12.23 & 14.43 & 14.03 & 9.00 & 8.76 & 25.91 \\
\hline
\end{tabular}



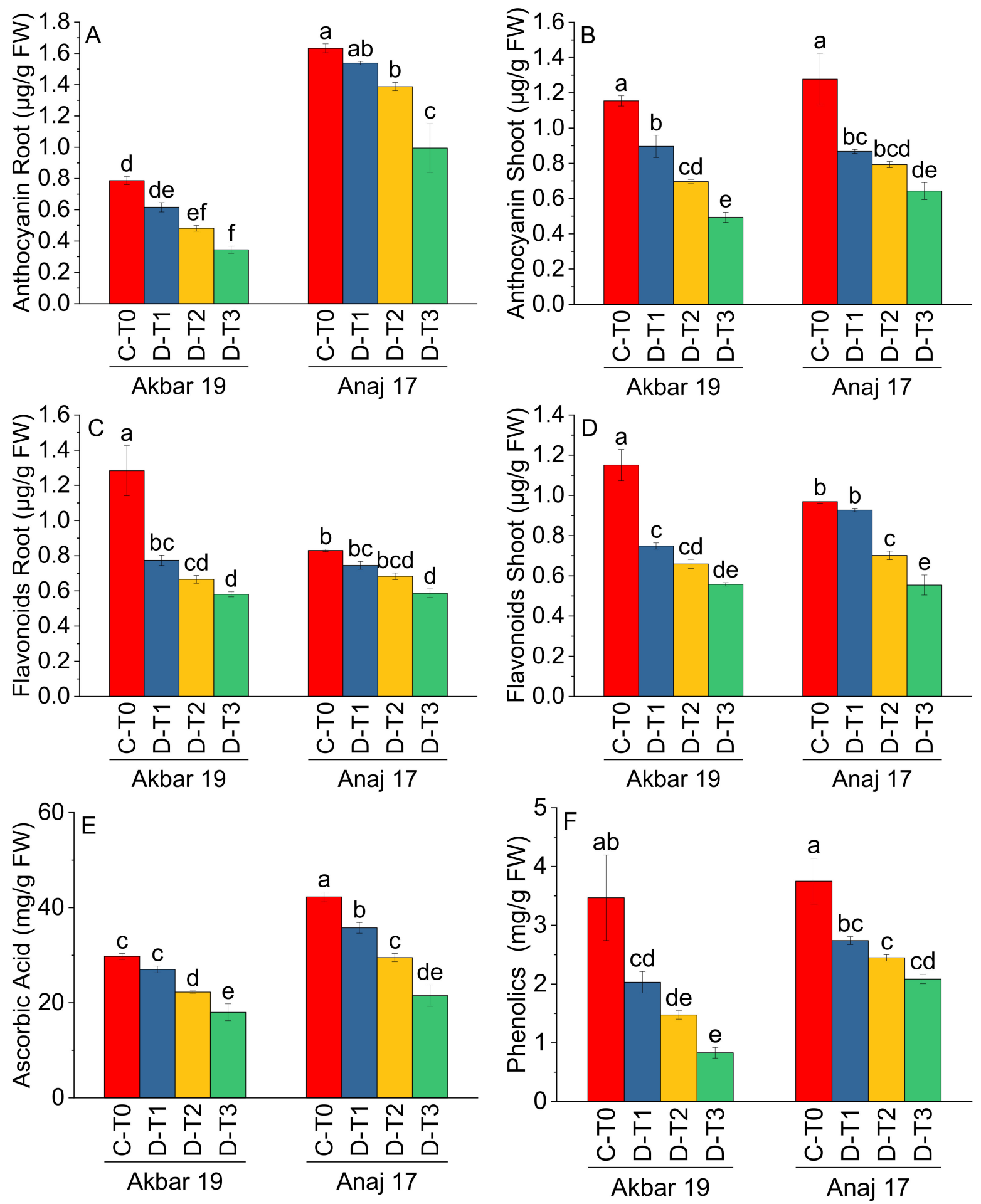

Figure 4. Effect of different application rates of thiamine in the presence of bacteria on anthocyanin, flavonoids, ascorbic acid and phenolics in root and shoot of two wheat cultivars (Akbar 19 and Anaj 17) under severe drought stress (35\%FC). Different values on bars showed significant difference at $p \leq 0.05$; LSD test. $(\mathbf{A})=$ anthocyanin in the root; $(\mathbf{B})=\operatorname{anthocyanin}$ in the shoot; $(\mathbf{C})=$ flavonoids in the root; $(\mathbf{D})=$ flavonoids in the $\operatorname{root} ;(\mathbf{E})=$ ascorbic acid; $(\mathbf{F})=$ phenolics. 


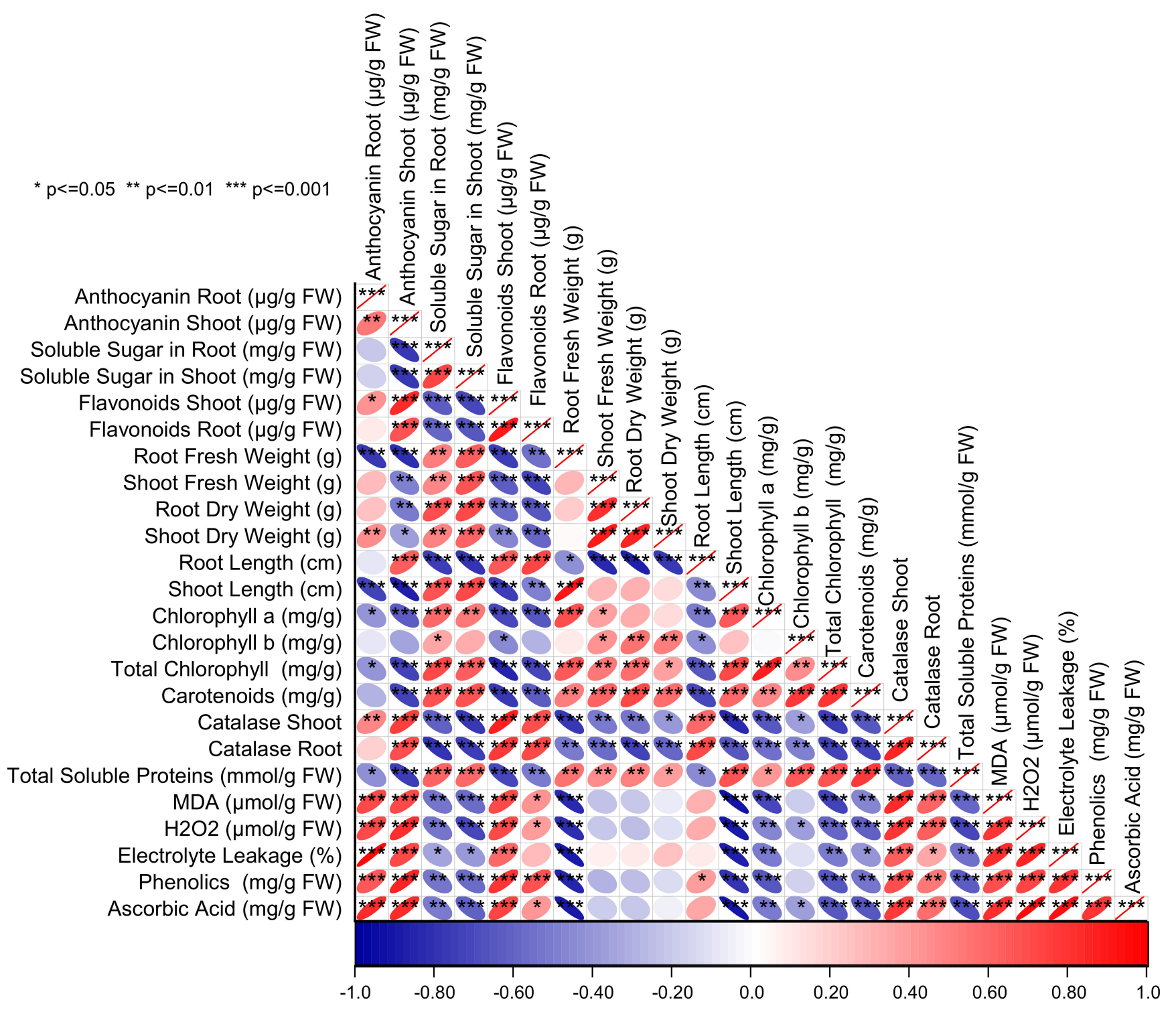

Figure 5. Pearson correlation of two wheat cultivars (Akbar 19 and Anaj 17) growth, physiology, antioxidants and chlorophyll contents under severe drought stress (35\%FC). Different values on bars showed significant difference at $p \leq 0.05$; LSD test.

\section{Discussion}

In the current study, control treatment plants showed a significant decrease in growth and yield attributes of both wheat varieties. The decline in productivity of both varieties was due to the adverse effects of drought. Gargallo-Garriga et al. [40] argued that limited water availability under drought stress restricted the shoot metabolic activity. Low shoot metabolic activities facilitate water conservation and transfer storage food from shoot towards root in the plant body. This transfer of food and conservation of water help in plant root elongation for survival under drought. Results of the current study also validated these facts. Root length was small where D-T3 was applied. However, RL was high in C-T0. It also signified that D-T3 application played an imperative role in alleviating drought stress in Anaj 2017 than Akbar 2019. Cell division is a key component that improved the growth of plants. Drought stress changed the osmotic potential of soil solution leading to poor cell division in roots and shoot.

Less division resulted in a significant decrease of dry weight, while poor water uptake due to change in osmotic potential decreased the fresh weight of root and shoot [41,42]. 
In the current study, similar results were noted. Increasing drought stress played an imperative role in the enhancement of stress generating ethylene [43]. The lipid layer in the membrane-bound organelles becomes degraded due to an increase in ethylene concentration. This stress generating ethylene activates chlorophyllase (chlase) when it comes in contact with chlorophyll. Activation of the enzyme chlorophyllase destroys the structure of chlorophyll. Thus plants showed chlorosis systems on leaves [44]. Our findings also justified the mechanism mentioned earlier. Low chlorophyll a, total chlorophyll, carotenoids in Anaj 2017 and Akbar 2019 resulted from drought-induced stress and might be higher biosynthesis of stress generating ethylene. Treatment D-T3 ameliorated growth conditions for Anaj 2017 and Akbar 2019 due to which chlorophyll a, total chlorophyll and carotenoids were improved. Thiamine or vitamin B1 is the key and primary metabolism for every living organism. Its activated form, "thiamine pyrophosphate (TPP)", acts as a cofactor for enzymes involved in synthesizing tricarboxylic acid cycle, amino acids and pentose phosphate pathway. In the current study, better production of total soluble protein by applying thiamine was associated with amino acids. The TPP controls many metabolic activities, i.e., acetyl-CoA biosynthesis, Krebs cycle and Calvin cycle directly associated with chlorophyll contents of leaves [45]. Moisture deficient conditions denature proteins and enzymes and to protect these, plants use several osmoprotectants and permit this osmotic adjustment. Proline and sugars are accumulated in cells to protect protein denaturalization under stress. Similar results were reported by Ahmed et al. [46] and Kishor et al. [47]. Osmoregulation maintains turgor potential in cells and improves physiological processes to cope with prevailing dehydration [11].

The higher synthesis of antioxidants in the current study, i.e., MDA, phenolics and $\mathrm{H}_{2} \mathrm{O}_{2}$, also validated the severe drought stress at C-T0. $\mathrm{H}_{2} \mathrm{O}_{2}$ has many physiological and growth-related roles in plants and regulates drought resistance in wheat. Chloroplast lipid peroxidation extent is estimated by measuring malondialdehyde (MDA) contents [48]. Flavonoids are well known low-molecular-weight secondary metabolites acting as antioxidants, anti-inflammatory, anti-mutagenic effects and plant pigmentation, which are proven to protect plants against drought stress [49]. A decrease in antioxidants by thiamine application (D-T3) signified it's imperative functioning towards alleviating drought stress.

\section{Conclusions}

In conclusion, the combined application of diazotrophic bacteria and thiamine solution under drought positively affected the growth, physiological and yield attributes of Anaj 2017 as compared to Akbar 2019. A significant improvement in fresh root weight, shoot dry weight, roots and shoot catalase validated the efficacious role of diazotrophic bacteria and thiamine solution over the control to mitigate drought stress in both wheat varieties. Among both wheat varieties, Anaj 2017 genotype was more drought tolerant than Akbar 2019. More investigation is suggested at the field level under different climatic conditions to declare D-T3 the best combination of diazotrophic bacteria and thiamine as the most effective amendment against drought.

Author Contributions: Conceptualization, S.F.A.; methodology, S.F.A., N.M., S.Y., A.K., M.S. and H.M.; software, S.F.A., N.M., S.Y., A.K. and H.M.; validation, S.F.A., N.M., S.Y., A.K. and H.M.; formal analysis, S.F.A., N.M., S.Y., A.K. and H.M.; investigation, S.F.A., N.M., M.S., S.Y., A.K. and H.M.; resources, E.M.E.; data curation, S.F.A., N.M., S.Y., A.K. and H.M.; writing—original draft preparation, S.F.A., N.M., S.Y., A.K. and H.M.; writing-review and editing, S.A.A., S.A.M.A., B.B., and E.M.E.; supervision, S.F.A.; project administration, E.M.E.; funding acquisition, E.M.E. All authors have read and agreed to the published version of the manuscript.

Funding: The authors extend their appreciation to the Scientific Research Deanship at King Khalid University and the Ministry of Education in Saudi Arabia for funding this research work through the project number IFP-KKU-2020/3.

Institutional Review Board Statement: Not applicable.

Informed Consent Statement: Not applicable. 


\section{Data Availability Statement: Not applicable.}

Conflicts of Interest: The authors declare no conflict of interest.

\section{References}

1. Zafar-ul-hye, M.; Naeem, M.; Danish, S.; Khan, M.J.; Fahad, S.; Datta, R.; Brtnicky, M.; Kintl, A.; Hussain, M.S.; El-esawi, M.A. Effect of cadmium-tolerant rhizobacteria on growth attributes and chlorophyll contents of bitter gourd under cadmium toxicity. Plants 2020, 9, 1386. [CrossRef] [PubMed]

2. Danish, S.; Tahir, F.A.; Rasheed, M.K.; Ahmad, N.; Ali, M.A.; Kiran, S.; Younis, U.; Irshad, I.; Butt, B. Effect of foliar application of Fe and banana peel waste biochar on growth, chlorophyll content and accessory pigments synthesis in spinach under chromium (IV) toxicity. Open Agric. 2019, 4, 381-390. [CrossRef]

3. Radziemska, M.; Gusiatin, Z.M.; Cydzik-Kwiatkowska, A.; Cerdà, A.; Pecina, V.; Bęś, A.; Datta, R.; Majewski, G.; Mazur, Z.; Dzięcioł, J.; et al. Insight into metal immobilization and microbial community structure in soil from a steel disposal dump that was phytostabilized with composted, pyrolyzed or gasified wastes. Chemosphere 2021, 272, 129576. [CrossRef] [PubMed]

4. Zafar-ul-Hye, M.; Tahzeeb-ul-Hassan, M.; Abid, M.; Fahad, S.; Brtnicky, M.; Dokulilova, T.; Datta, R.; Danish, S. Potential role of compost mixed biochar with rhizobacteria in mitigating lead toxicity in spinach. Sci. Rep. 2020, 10, 12159. [CrossRef] [PubMed]

5. Zafar-Ul-hye, M.; Naeem, M.; Danish, S.; Fahad, S.; Datta, R.; Abbas, M.; Rahi, A.A.; Brtnicky, M.; Holátko, J.; Tarar, Z.H.; et al. Alleviation of cadmium adverse effects by improving nutrients uptake in bitter gourd through cadmium tolerant rhizobacteria. Environments 2020, 7, 54. [CrossRef]

6. Zafar-ul-Hye, M.; Shahjahan, A.; Danish, S.; Abid, M.; Qayyum, M.F. Mitigation of cadmium toxicity induced stress in wheat by ACC-deaminase containing PGPR isolated from cadmium polluted wheat rhizosphere. Pakistan J. Bot. 2018, 50, 1727-1734.

7. Ahmed, N.; Ahsen, S.; Ali, M.A.; Hussain, M.B.; Hussain, S.B.; Rasheed, M.K.; Butt, B.; Irshad, I.; Danish, S. Rhizobacteria and silicon synergy modulates the growth, nutrition and yield of mungbean under saline soil. Pakistan J. Bot. 2020, 52, 9-15. [CrossRef]

8. Rafiullah; Jamal Khan, M.; Muhammad, D.; Fahad, S.; Adnan, M.; Wahid, F.; Alamri, S.; Khan, F.; Muhammad Dawar, K.; Irshad, I.; et al. Phosphorus nutrient management through synchronization of application methods and rates in wheat and maize crops. Plants 2020, 9, 1389. [CrossRef]

9. Wahid, F.; Fahad, S.; Danish, S.; Adnan, M.; Yue, Z.; Saud, S.; Siddiqui, M.H.; Brtnicky, M.; Hammerschmiedt, T.; Datta, R. Sustainable Management with Mycorrhizae and Phosphate Solubilizing Bacteria for Enhanced Phosphorus Uptake in Calcareous Soils. Agriculture 2020, 10, 334. [CrossRef]

10. Danish, S.; Zafar-ul-Hye, M.; Fahad, S.; Saud, S.; Brtnicky, M.; Hammerschmiedt, T.; Datta, R. Drought stress alleviation by ACC deaminase producing Achromobacter xylosoxidans and Enterobacter cloacae, with and without timber waste biochar in maize. Sustainability 2020, 12, 6286. [CrossRef]

11. Seleiman, M.F.; Al-Suhaibani, N.; Ali, N.; Akmal, M.; Alotaibi, M.; Refay, Y.; Dindaroglu, T.; Abdul-Wajid, H.H.; Battaglia, M.L. Drought stress impacts on plants and different approaches to alleviate its adverse effects. Plants 2021, 10, 259. [CrossRef] [PubMed]

12. Danish, S.; Zafar-Ul-Hye, M.; Hussain, S.; Riaz, M.; Qayyum, M.F. Mitigation of drought stress in maize through inoculation with drought tolerant ACC deaminase containing PGPR under axenic conditions. Pakistan J. Bot. 2020, 52. [CrossRef]

13. Gilani, M.; Danish, S.; Ahmed, N.; Rahi, A.A.; Akrem, A.; Younis, U.; Irshad, I.; Iqbal, R.K. Mitigation of drought stress in spinach using individual and combined applications of salicylic acid and potassium. Pakistan J. Bot. 2020, 52, 1505-1513. [CrossRef]

14. Janjua, P.Z.; Samad, G.; Khan, N. Climate change and wheat production in Pakistan: An autoregressive distributed lag approach. NJAS Wageningen J. Life Sci. 2014, 68, 13-19. [CrossRef]

15. Izhar Shafi, M.; Adnan, M.; Fahad, S.; Wahid, F.; Khan, A.; Yue, Z.; Danish, S.; Zafar-ul-Hye, M.; Brtnicky, M.; Datta, R. Application of Single Superphosphate with Humic Acid Improves the Growth, Yield and Phosphorus Uptake of Wheat (Triticum aestivum L.) in Calcareous Soil. Agronomy 2020, 10, 1224. [CrossRef]

16. Camilios-Neto, D.; Bonato, P.; Wassem, R.; Tadra-Sfeir, M.Z.; Brusamarello-Santos, L.C.C.; Valdameri, G.; Donatti, L.; Faoro, H.; Weiss, V.A.; Chubatsu, L.S.; et al. Dual RNA-seq transcriptional analysis of wheat roots colonized by Azospirillum brasilense reveals up-regulation of nutrient acquisition and cell cycle genes. BMC Genom. 2014, 15, 378. [CrossRef]

17. Creus, C.M.; Sueldo, R.J.; Barassi, C.A. Water relations and yield in Azospirillum-inoculated wheat exposed to drought in the field. Can. J. Bot. 2004, 82, 273-281. [CrossRef]

18. Pérez-Jiménez, M.; Tallón, C.I.; Pérez-Tornero, O. Inducing mutations in Citrus spp.: Sensitivity of different sources of plant material to gamma radiation. Appl. Radiat. Isot. 2020, 157, 109030. [CrossRef]

19. Amir, K.; Hussain, S.; Shuaib, M.; Hussain, F.; Urooj, Z.; Khan, W.M.; Zeb, U.; Ali, K.; Zeb, M.A.; Hussain, F. Effect of gamma irradiation on OKRA (Abelmoschus esculentus L.). Shengtai Xuebao Acta Ecol. Sin. 2018, 38, 368-373. [CrossRef]

20. Carvalho, T.L.G.; Ballesteros, H.G.F.; Thiebaut, F.; Ferreira, P.C.G.; Hemerly, A.S. Nice to meet you: Genetic, epigenetic and metabolic controls of plant perception of beneficial associative and endophytic diazotrophic bacteria in non-leguminous plants. Plant Mol. Biol. 2016, 90, 561-574. [CrossRef]

21. Jabeen, M.; Akram, N.A.; Ashraf, M.; Alyemeni, M.N.; Ahmad, P. Thiamin stimulates growth and secondary metabolites in turnip (Brassica rapa L.) leaf and root under drought stress. Physiol. Plant. 2020. [CrossRef] 
22. Ors, S.; Suarez, D.L. Spinach biomass yield and physiological response to interactive salinity and water stress. Agric. Water Manag. 2017, 190, 31-41. [CrossRef]

23. Hamada, A.; Al-Hakimi, A. Exogenous ascorbic acid or thiamine increases the resistance of sunflower and maize plants to salt stress. Acta Agron. Hungarica 2009, 57, 335-347. [CrossRef]

24. Khan, K.; Shrewry, P.R. Wheat: Chemistry and Technology, 4th ed.; Elsevier: Amsterdam, The Netherlands, 2009; ISBN 9780128104545.

25. Arshad, M.; Amjath-Babu, T.S.; Aravindakshan, S.; Krupnik, T.J.; Toussaint, V.; Kächele, H.; Müller, K. Climatic variability and thermal stress in Pakistan's rice and wheat systems: A stochastic frontier and quantile regression analysis of economic efficiency. Ecol. Indic. 2018, 89, 496-506. [CrossRef]

26. Miedaner, T.; Juroszek, P. Climate change will influence disease resistance breeding in wheat in Northwestern Europe. Theor. Appl. Genet. 2021. [CrossRef] [PubMed]

27. Arnon, D.I. Copper Enzymes in Isolated Chloroplasts. Polyphenoloxidase in Beta vulgaris. Plant Physiol. 1949, 24, 1-15. [CrossRef]

28. Heath, R.L.; Packer, L. Photoperoxidation in isolated chloroplasts. Arch. Biochem. Biophys. 1968, 125, 189-198. [CrossRef]

29. Jana, S.; Choudhuri, M.A. Glycolate metabolism of three submersed aquatic angiosperms during ageing. Aquat. Bot. 1982, 12, 345-354. [CrossRef]

30. Dionisio-Sese, M.L.; Tobita, S. Antioxidant responses of rice seedlings to salinity stress. Plant Sci. 1998, 135, 1-9. [CrossRef]

31. Sakharov, I.Y.; Ardila, G.B. Variations of peroxidase activity in cocoa (Theobroma cacao L.) beans during their ripening, fermentation and drying. Food Chem. 1999, 65, 51-54. [CrossRef]

32. Aebi, H. Catalase in vitro. In Methods in Enzymology; Academic Press Inc.: Cambridge, MA, USA, 1984; Volume 105, pp. 121-126.

33. Lewis, C.E.; Walker, J.R.L.; Lancaster, J.E.; Sutton, K.H. Determination of anthocyanins, flavonoids and phenolic acids in potatoes. I: Coloured cultivars of Solanum tuberosum L. J. Sci. Food Agric. 1998, 77, 45-57. [CrossRef]

34. Bray, H.G.; Thorpe, W.V. Analysis of phenolic compounds of interest in metabolism. Methods Biochem. Anal. 1954, 1, 27-52.

35. Pękal, A.; Pyrzynska, K. Evaluation of Aluminium Complexation Reaction for Flavonoid Content Assay. Food Anal. Methods 2014, 7, 1776-1782. [CrossRef]

36. Dubois, M.; Gilles, K.A.; Hamilton, J.K.; Rebers, P.A.; Smith, F. Colorimetric Method for Determination of Sugars and Related Substances. Anal. Chem. 1956, 28, 350-356. [CrossRef]

37. Azuma, K.; Nakayama, M.; Koshioka, M.; Ippoushi, K.; Yamaguchi, Y.; Kohata, K.; Yamauchi, Y.; Ito, H.; Higashio, H. Phenolic antioxidants from the leaves of Corchorus olitorius L. J. Agric. Food Chem. 1999, 47, 3963-3966. [CrossRef] [PubMed]

38. Steel, R.G.; Torrie, J.H.; Dickey, D.A. Principles and Procedures of Statistics: A Biometrical Approach, 3rd ed.; McGraw Hill Book International Co.: Singapore, 1997.

39. OriginLab Corporation. OriginPro; OriginLab: Northampton, MA, USA, 2021.

40. Gargallo-Garriga, A.; Sardans, J.; Pérez-Trujillo, M.; Rivas-Ubach, A.; Oravec, M.; Vecerova, K.; Urban, O.; Jentsch, A.; Kreyling, J.; Beierkuhnlein, C.; et al. Opposite metabolic responses of shoots and roots to drought. Sci. Rep. 2014, 4, 6829. [CrossRef] [PubMed]

41. Zeiger, E.; Taiz, L. Plant Physiology; Sinauer Associates Inc.: Sunderland, MA, USA, 2010.

42. Paul, S.; Aggarwal, C.; Manjunatha, B.; Rathi, M.S. Characterization of osmotolerant rhizobacteria for plant growth promoting activities in vitro and during plant-microbe association under osmotic stress. Indian J. Exp. Biol. 2018, 56, 582-589.

43. Glick, B.; Penrose, D.; Li, J. A Model For the Lowering of Plant Ethylene Concentrations by Plant Growth-promoting Bacteria. J. Theor. Biol. 1998, 190, 63-68. [CrossRef]

44. Matile, P.; Schellenberg, M.; Vicentini, F. Planta Localization of chlorophyllase in the chloroplast envelope. Planta 1997, 201, 96-99. [CrossRef]

45. Du, Q.; Wang, H.; Xie, J. Thiamin (vitamin B1) biosynthesis and regulation: A rich source of antimicrobial drug targets? Int. J. Biol. Sci. 2011, 7, 41-52. [CrossRef]

46. Ahmed, K.; Shabbir, G.; Ahmed, M.; Shah, K.N. Phenotyping for drought resistance in bread wheat using physiological and biochemical traits. Sci. Total Environ. 2020, 729, 139082. [CrossRef] [PubMed]

47. Kishor, P.B.K.; Rajesh, K.; Reddy, P.S.; Seiler, C.; Sreenivasulu, N. Drought stress tolerance mechanisms in barley and its relevance to cereals. In Biotechnology in Agriculture and Forestry; Kumlehn, J., Stein, N., Eds.; Springer: Berlin/Heidelberg, Germany, 2014; Volume 69, pp. 161-179.

48. Shan, C.; Zhang, S.; Ou, X. The roles of H2S and $\mathrm{H} 2 \mathrm{O} 2$ in regulating AsA-GSH cycle in the leaves of wheat seedlings under drought stress. Protoplasma 2018, 255, 1257-1262. [CrossRef] [PubMed]

49. Kleinenkuhnen, N.; Büchel, F.; Gerlich, S.C.; Kopriva, S.; Metzger, S. A novel method for identification and quantification of sulfated flavonoids in plants by neutral loss scan mass spectrometry. Front. Plant Sci. 2019, 10, 885. [CrossRef] [PubMed] 